\title{
OPTIMASI PENGOLAHAN KEMBANG GULA JELLY CAMPURAN KULIT DAN DAGING BUAH NAGA SUPER MERAH (Hylocereus costaricensis) DAN PRAKIRAAN BIAYA PRODUKSI
}

\section{Rekna Wahyuni}

\begin{abstract}
Abstrak: Tujuan penelitian adalah menentukan jenis dan proporsi bahan pengenyal pada pembuatan kembang gula jelly, mengetahui persentase kulit buah naga super merah (Hylocereus costaricensis) yang optimal pada pembuatan kembang gula jelly kulit buah naga merah untuk meningkatkan kualitas kembang gula jelly yang dihasilkan dan mengetahui biaya produksi dan kelayakan usaha pembuatan kembang gula jelly kulit buah naga merah (Hylocereus costaricensis). Penelitian dilakukan dalam dua tahap. Penelitian tahap I terdiri dari 2 faktor (jenis dan persentase bahan pengenyal), faktor pertama terdiri dari 2 level (tepung karaginan dan tepung agar-agar) dan faktor kedua terdiri dari 4 level (2\% ; 4\% ; $6 \%$; dan $8 \%$ b/b). Analisa dilakukan menggunakan uji Organoleptik hedonic scale (warna, aroma, rasa dan tekstur) . Penelitian tahap II menggunakan Rancangan Acak Tunggal, dengan perlakuan persentase menambahkan kulit buah naga super merah , terdiri dari 6 level $(0 \%$; $20 \%$; $40 \%$; $60 \%$; $80 \%$ dan 100 $\%)$. Data yang didapat dari penelitian tahap I pada masing-masing variabel dianalisa dengan Uji Friedman. Perlakuan terbaik dianalisa menggunakan metode indeks efektifitas deGarmo et al., (1984) yang dimodifikasi oleh Susrini (2003). Penelitian tahap II dianalisa dengan uji $\mathrm{F}$ dan jika terdapat perbedaan dianalisa dengan Uji BNT 5\%. Pemilihan perlakuan terbaik menggunakan Indeks Efektifitas. Selanjutnya perlakuan terbaik yang didapatkan dari uji Indeks Efektifitas diuji Analisa biaya produksi dan kelayakan usaha dengan menggunakan Analisa Finansial. Hasil penelitian didapatkan kombinasi perlakuan persentase kulit $100 \%$ (tanpa penambahan daging buah) dan bahan pengenyal berupa tepung karaginan $6 \% \mathrm{~b} / \mathrm{b}$ merupakan kombinasi yang paling baik dan memenuhi syarat mutu kembang gula yang ditetapkan dalam SNI 3547.2-2008, dengan karakteristik sebagai berikut: rerata kadar air 20.602\% ; kadar abu $1.267 \%$; gula reduksi $20.700 \%$; serat kasar $1.428 \%$; antioksidan (DPPH) $6.493 \%$ serta rerata tingkat kesukaan panelis terhadap rasa 3.900 ; warna 4.667 ; aroma 3.533 dan tekstur 4.100. Berdasarkan analisa prakiraan biaya produksi dan finansial didapatkan pengolahan kembang gula kulit buah naga super merah layak diproduksi dengan lokasi di wilayah Kabupaten Malang. Perhitungan BEP dicapai pada volume penjualan $2.131 \mathrm{Kg}$ atau senilai Rp. 83,918,794,00. Nilai payback period dicapai pada 1 tahun 3 bulan 3 hari. Nilai Net Present Value (NPV) sebesar Rp. 52.868.819,00. Nilai Profitability Index (PI) sebesar 1.575.

Kata kunci: kulit buah naga super merah, kembang gula jelly, karaginan, serat, antioksidan
\end{abstract}


Kembang gula atau permen sangat lekat dengan keseharian masyarakat, bukan hanya anak-anak tetapi juga remaja dan orang dewasa. Kembang gula yang beredar di tengah masyarakat terdiri dari dua jenis, keras (hard candy) dan lunak (soft candy). Perbedaan tersebut didasarkan pada teksturnya. Kembang gula keras adalah kembang gula yang teksturnya padat dan dimakan dengan cara menghisap. Kembang gula jenis ini larut bersama air liur sementara kembang gula lunak ditandai dengan teksturnya yang lunak. Jenis kembang gula ini bukan untuk dihisap melainkan dikunyah.

Menurut SNI 3547.2-2008 kembang gula jelly termasuk dalam kembang gula lunak. Kembang gula lunak dibagi menjadi kembang gula lunak bukan jelly dan kembang gula lunak jelly. Kembang gula lunak jelly adalah kembang gula bertekstur lunak , yang diproses dengan penambahan komponen hidrokoloid seperti agar, gum, pektin, pati, karaginan, gelatin dan lain-lain yang digunakan untuk modifikasi tekstur sehingga menghasilkan produk yang kenyal, harus dicetak dan diproses aging terlebih dahulu sebelum dikemas. Proses aging yaitu penyimpanan produk dalam kondisi dan waktu tertentu untuk mencapai karakter produk yang diinginkan.

Pada dasarnya kandungan kalori dalam satu butir kembang gula cukup rendah, sekitar 20-30 kalori. Selain kalori, kembang gula sebetulnya sama sekali tidak memiliki kandungan gizi. Padahal kelebihan kalori yang dikonsumsi akan ditumpuk dalam bentuk cadangan lemak yang menyebabkan terjadinya kelebihan berat badan. Kegemukan berkaitan erat dengan penyakit kencing manis dan gangguan jantung. Jadi sebetulnya kembang gula termasuk golongan junk food atau "makanan sampah" yang miskin akan zat gizi (Anonymous, 2008b). Disamping itu flavour serta gelatin yang digunakan dalam pembuatan kembang gula jelly kerap diragukan kehalalannya, karena sering digunakan alkohol sebagai pelarut flavor, dan gelatin didapatkan dari jaringan tubuh binatang yang tidak halal (Anonymous, 2008a).

Untuk menghilangkan anggapan bahwa kembang gula adalah makanan yang tidak sehat untuk dikonsumsi maka perlu dibuat jenis kembang gula yang mempunyai manfaat bagi konsumen baik anak-anak, remaja, maupun orang dewasa. Bahan yang ditambahkan harus mempunyai nilai nutrisi yang tinggi.

Bahan utama yang ditambahkan dalam penelitian ini adalah karaginan dan agar-agar yang berasal dari rumput laut serta buah naga super merah Hylocereus costaricensis yang kini telah banyak dibudidayakan dan sangat populer serta memiliki peluang besar untuk disebarluaskan di Indonesia (Sutomo, 2007).

Kembang gula jelly yang berasal dari rumput laut mempunyai karakteristik tertentu yaitu kekenyalan, rasa manis yang cukup. Dengan penambahan flavor dan pewarna seperti buah-buahan akan memiliki aroma dan warna yang menarik. Keunggulan 
kembang gula jelly rumput laut (Anonymous, 2009a) adalah:

- Kaya akan nutrisi bila dibandingkan dengan produk sejenis di pasaran yang mengandung bahan kimia.

- Bahan/peralatan serta proses pembuatannya cukup sederhana, sehingga dapat dilakukan dalam skala rumah tangga.

- Memiliki bentuk, aroma serta warna yang menarik sehingga dapat menarik minat konsumen khususnya bagi anak-anak.

Karaginan dan agar-agar adalah produk olahan dari rumput laut. Bahan tambahan ini membuat kembang gula jelly menjadi lembut dan kenyal serta mengandung serat yang tinggi (Anonymous, 2008c). Menurut Caturini (2009) pengolahan rumput laut menjadi kembang gula jelly aneka rasa ini, selain menyehatkan dan murah juga menghasilkan keuntungan ekonomi di pesisir pantai Jawa Timur.

Kembang gula jelly disukai karena mempunyai rasa buah-buahan yang segar dan warna yang cerah, tetapi selama ini yang banyak digunakan oleh produsen adalah berupa perasa makanan atau flavour dan zat pewarna buatan, sehingga keamanannya kurang dapat dipertanggung jawabkan. Penambahan juice buah segar dan pewarna alami merupakan alternatif yang sangat baik untuk mengatasi permasalahan ini. Salah satu buah yang memenuhi kriteria ini adalah buah naga jenis super merah (Hylocereus costaricensis) karena mempunyai rasa yang manis, segar, beraroma dan memiliki warna yang merah terang tanpa harus diberi zat pewarna tambahan lain sehingga menghilangkan keraguan akan berakibat buruk pada kesehatan (Anonymous, 2007b).

Tanaman buah naga dalam satu tahun bisa berbuah tiga kali, dan produksinya bisa terus meningkat, asalkan dirawat dengan baik . Tanaman akan mulai berbuah pada umur 11 - 17 bulan dan dalam sekali tanam usianya bisa bertahan sampai 30 tahun. Pada tahun pertama, setiap batang pohon bisa menghasilkan 1-2 $\mathrm{kg}$, tahun kedua, bisa sampai $4 \mathrm{~kg}$, pada tahun ke tiga bisa mencapai $8 \mathrm{~kg}$, dan seterusnya bertambah setiap tahun. Dari lahan seluas satu hektar bisa ditanami 6.000 pohon (Rahmatillah, 2009).

Kota Malang dinilai cocok untuk tanaman buah naga merah karena berada 400-700 di permukaan laut. Walaupun memiliki udara yang cukup sejuk, namun sinar matahari yang cukup merupakan modal untuk pertumbuhan buah naga merah (Anonymous, 2009e). Lahan yang digunakan untuk budidaya buah naga dapat ditumpang sari dengan tanaman lainnya, yakni padi, semangka dan sayur-sayuran (Anonymous, 2009d).

Luas lahan buah naga super merah (Hylocereus costaricensis) di Malang menurut Tulus Subagyo dalam Anonymous (2009g) adalah sekitar 10 hektar tersebar di Malang Raya (kodya Malang, Kabupaten Malang dan Kota Batu), ditanami sekitar 40.000 batang pohon naga super merah (Hylocereus costaricensis) dimana setiap batang menghasilkan $2-8 \mathrm{~kg}$ buah segar. Jadi 
potensi buah naga super merah di Malang Raya sekitar 80 - 320 ton per tahun buah segar. Bila 10\% saja diolah menjadi produk makanan atau minuman maka potensi dari kulitnya (30 - 35\% berat buah) sekitar 2,4 - 9,6 ton per tahun. Menurut Ridwan Rahmatillah (2009) selain di Malang, buah naga super merah juga dikembangkan di Desa Purwodadi Kabupaten Pasuruan Jawa Timur seluas 17 hektar sejak tahun 2003 sampai tahun 2010, Jember, Lumajang, Batam dan beberapa kota lain di Indonesia.

Menurut Saati (2009), kulit buah naga berjumlah 30-35 \% dari berat buahnya dan seringkali hanya dibuang sebagai sampah saja. Padahal hasil penelitian menunjukkan kulit buah naga merah (Hylocereus costaricensis) mengandung antosianin yang dapat merendahkan kadar kolesterol (Kanner et al. 2001).

Menurut Li Chen Wu (2005) daging dan kulit buah naga jenis super merah (Hylocereus costaricensis) sama-sama kaya polyphenol dan sumber antioksidan yang baik. Bahkan menurut studi yang dilakukannya terhadap total phenolic konten, aktivitas antioksidan dan kegiatan antiproliferative, kulit buah naga merah adalah lebih kuat inhibitor pertumbuhan sel-sel kanker daripada dagingnya.

Permasalahan yang timbul adalah bagaimana caranya membuat kembang gula jelly dari kulit buah naga super merah (Hylocereus costaricensis) yang layak untuk diproduksi serta berapakah kandungan bahan pengenyal dan persentase kulit buah naga super merah yang optimal pada pembuatan kembang gula jelly kulit buah naga super merah sehingga memenuhi syarat mutu kembang gula yang ditetapkan dalam SNI 3547.2-2008.

\section{METODE PENELITIAN}

Penelitian dilaksanakan pada bulan Maret 2010 sampai bulan Mei 2010 bertempat di Laboratorium Rekayasa Teknologi Industri Pertanian Universitas Brawijaya Malang dan Laboratorium Teknologi Hasil Pertanian Universitas Muhammadiyah Malang.

Rancangan penelitian meliputi :

\section{Penelitian Tahap I}

Dengan meneliti pembuatan kembang gula jelly dengan perlakuan macam dan persentase bahan pengenyal. Metode penelitian yang digunakan adalah Uji Friedman dimana terdiri dari 2 faktor, faktor pertama terdiri dari 2 level dan faktor kedua terdiri dari 4 level.

- Faktor pertama yaitu : Macam Bahan Pengenyal (B) yang terdiri dari :

B1: Tepung Karaginan

B2: Tepung Agar-agar

- Faktor kedua yaitu persentase Bahan Pengenyal (P) yang terdiri dari :

P1 : $2 \%$ b/b

$\mathrm{P} 2$ : $4 \% \mathrm{~b} / \mathrm{b}$

P3 : $6 \% \mathrm{~b} / \mathrm{b}$

$\mathrm{P} 4$ : $8 \% \mathrm{~b} / \mathrm{b}$

- Dari kedua faktor tersebut didapat 8 kombinasi perlakuan yaitu: $\mathrm{B}_{1} \mathrm{P}_{1}$ : Tepung Karaginan $2 \%$ b/b $\mathrm{B}_{1} \mathrm{P}_{2}$ : Tepung Karaginan 4\% b/b 


$$
\begin{aligned}
& \mathrm{B}_{1} \mathrm{P}_{3} \text { : Tepung Karaginan } 6 \% \mathrm{~b} / \mathrm{b} \\
& \mathrm{B}_{1} \mathrm{P}_{4}: \text { Tepung Karaginan } 8 \% \mathrm{~b} / \mathrm{b} \\
& \mathrm{B}_{2} \mathrm{P}_{1} \text { : Tepung Agar-agar } 2 \% \mathrm{~b} / \mathrm{b} \\
& \mathrm{B}_{2} \mathrm{P}_{2} \text { : Tepung Agar-agar } 4 \% \mathrm{~b} / \mathrm{b} \\
& \mathrm{B}_{2} \mathrm{P}_{3} \text { : Tepung Agar-agar } 6 \% \mathrm{~b} / \mathrm{b} \\
& \mathrm{B}_{2} \mathrm{P}_{4} \text { : Tepung Agar-agar } 8 \% \mathrm{~b} / \mathrm{b}
\end{aligned}
$$

\section{Penelitian Tahap II \\ Penelitian tahap kedua} merupakan lanjutan dari hasil penelitian tahap I, dimana hasil yang paling baik pada penelitian tahap pertama merupakan dasar penelitian tahap kedua. Pada penelitian tahap ke II ini menggunakan Rancangan Acak Tunggal, yaitu dengan menambahkan kulit buah naga super merah ke dalam sari buah naga super merah dengan persentase yang berbeda yaitu persentase kulit $(\mathrm{K})$ yang terdiri dari :

$$
\begin{array}{ll}
\mathrm{K} 1 & : 0 \% \\
\mathrm{~K} 2 & : 20 \% \\
\mathrm{~K} 3 & : 40 \% \\
\mathrm{~K} 4 & : 60 \% \\
\mathrm{~K} 5 & : 80 \% \\
\mathrm{~K} 6 & : 100 \%
\end{array}
$$

Masing-masing perlakuan diulang sebanyak tiga kali sehingga didapat 18 perlakuan

\section{Analisa Data}

Data yang didapat dari hasil pengamatan setelah perlakuan penelitian tahap I pada masing-masing variabel dimasukkan dalam tabel untuk dianalisa Uji Friedman. Perlakuan terbaik dianalisa menggunakan metode indeks efektifitas deGarmo et al., (1984) yang dimodifikasi oleh Susrini (2003).
Sedangkan penelitian tahap II dianalisa dengan uji $\mathrm{F}$ dan jika terdapat perbedaan dianalisa dengan Uji BNT 5\%. Pemilihan perlakuan terbaik (penentuan titik optimum) menggunakan Indeks Efektifitas deGarmo et al., (1984) yang dimodifikasi oleh Susrini (2003). Selanjutnya perlakuan terbaik yang didapatkan dari uji Indeks Efektifitas diuji Analisa biaya produksi dan kelayakan usaha dengan menggunakan Analisa Finansial.

\section{Analisa Biaya Produksi dan Kelayakan Usaha}

Analisa biaya produksi dan kelayakan usaha dilakukan terhadap perlakuan macam dan proporsi bahan pengenyal serta persentase kulit buah naga super merah (Hylocereus costaricensis) yang terpilih. Kriteriakriteria kelayakan yang akan diukur meliputi (Husnan dan Suwarsono, 1991) :

- Net Present Value

- Break Even Point (kg, Rp)

- Profitability Indeks (PI)

- Payback Period (PP)

Variabel yang diteliti adalah :

a. Biaya investasi

Parameternya adalah : Harga mesin, peralatan, harga tanah dan bangunan

b. Biaya Operasional Parameternya adalah :

- Harga bahan baku dan gaji pekerja

- Biaya penggunaan air, listrik, telepon dan bahan bakar

c. Kelayakan Finansial 
Parameternya adalah :

- Harga bahan baku, harga mesin dan peralatan

- Biaya penggunaan air, listrik, telepon dan bahan bakar

- Harga tanah dan bangunan serta gaji pekerja

\section{HASIL PENELITIAN \\ Penelitian tahap I}

Penelitian tahap I bertujuan untuk menentukan jenis dan proporsi bahan pengenyal yang optimal dalam pembuatan kembang gula jelly. Penelitian ini menggunakan 2 jenis bahan pengenyal yaitu tepung karaginan dan agar-agar serta 4 macam proporsi bahan pengenyal yaitu $2 \% \mathrm{~b} / \mathrm{b}$, $4 \% \mathrm{~b} / \mathrm{b}, 6 \% \mathrm{~b} / \mathrm{b}, 8 \% \mathrm{~b} / \mathrm{b}$ sesuai dengan penelitian pendahuluan yang telah dilakukan.

Pengamatan pada penelitian tahap I meliputi uji organoleptik, rasa, warna, aroma dan tekstur. Pendekatan dengan penilaian organoleptik dianggap paling praktis lebih murah biayanya. Pengujian sensori (uji panel) berperan penting dalam pengembangan produk dengan meminimalkan resiko dalam pengambilan keputusan. Panelis dapat mengidentifikasi sifat-sifat sensori yang akan membantu untuk mendeskripsikan produk.

Uji organoleptik yang digunakan adalah uji afektif (affective test). Pengujian Afektif adalah menguji kesukaan dan/atau penerimaan terhadap suatu produk dan membutuhkan jumlah panelis tidak dilatih yang banyak yang sering dianggap untuk mewakili kelompok konsumen tertentu (Anonymous, 2006). Dalam penelitian ini digunakan panelis tidak dilatih sebanyak 30 orang dari berbagai kalangan baik usia tingkat pendidikan, gender maupun pekerjaan.

\section{Rasa}

Bahan pangan pada umumnya tidak hanya memilki salah satu rasa melainkan gabungan berbagai macam rasa secara terpadu. Rasa lebih banyak melibatkan panca indera yaitu lidah, dengan lidah senyawa dapat dikenali rasanya.

Hasil uji organoleptik menunjukkan bahwa rerata ranking kesukaan panelis terhadap rasa kembang gula jelly berkisar antara 2,33 - 3,73. Semakin tinggi rerata ranking kesukaan panelis, maka tingkat kesukaan panelis terhadap rasa kembang gula jelly semakin besar. Rerata ranking tingkat kesukaan panelis terhadap rasa kembang gula jelly ditunjukkan pada Gambar 1.

Rerata nilai kesukaan panelis terhadap rasa kembang gula jelly mempunyai nilai terendah 2,33 didapatkan dari bahan pengenyal tepung agar-agar $4 \% \mathrm{~b} / \mathrm{b}$ dan $6 \% \mathrm{~b} / \mathrm{b}$, sedangkan nilai tertinggi 3,73 didapatkan dari bahan pengenyal tepung karaginan $6 \% \mathrm{~b} / \mathrm{b}$.

Hasil analisis Uji Friedman menunjukkan bahwa pembuatan kembang gula jelly dengan dua jenis bahan pengenyal (tepung karaginan dan tepung agar-agar) serta dengan empat variasi persentase $(2 \% \mathrm{~b} / \mathrm{b}, 4 \%$ b/b, 6\% b/b dan 8\% b/b) memberikan pengaruh nyata terhadap rerata kesukaan rasa kembang gula jelly. Kombinasi perlakuan terbaik tingkat 


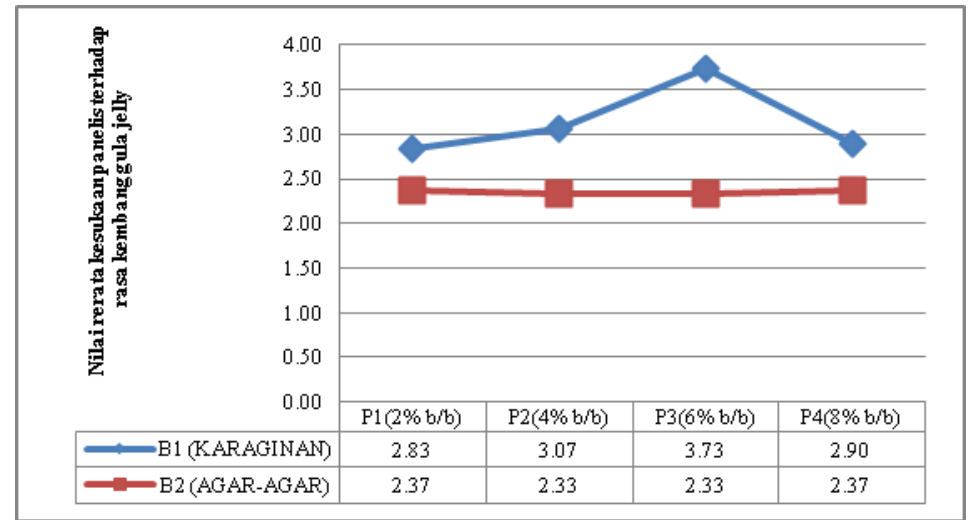

Gambar 1. Rerata kesukaan panelis terhadap rasa kembang gula jelly

$\begin{aligned} & \text { kesukaan rasa diperoleh dari } \\ & \text { kembang gula jelly berbahan } \\ & \text { pengenyal karaginan dengan }\end{aligned}$
$\begin{aligned} & \text { persentase } 6 \% \text { b/b. } \\ & \text { Perbedaan rasa disebabkan }\end{aligned}$
penggunaan bahan pengenyal yang
berbeda, masing-masing bahan
pengenyal memiliki sifat dan karakter
yang berbeda. Karaginan dan agar-agar
berasal dari rumput laut yang tidak
memiliki rasa khas, sehingga rasa
manis gula lebih tajam dan menonjol.

\section{Warna}

Warna merupakan indikator yang pertama kali dilihat dan diamati oleh konsumen karena warna merupakan faktor kenampakan yang langsung dapat dilihat oleh konsumen (Kartika, 1988). Warna makanan dapat menarik dan mempengaruhi selera konsumen, sehingga dengan warna dapat membangkitkan selera makan. Bahkan warna juga dapat menjadi

petunjuk bagi kualitas dari makanan yang dihasilkan.

Hasil uji organoleptik menunjukkan bahwa rerata ranking kesukaan panelis terhadap warna kembang gula jelly berkisar antara 2,63 - 3,67. Semakin tinggi rerata ranking kesukaan panelis, maka tingkat kesukaan panelis terhadap warna kembang gula jelly semakin besar. Rerata ranking tingkat kesukaan panelis terhadap warna kembang gula jelly ditunjukkan pada Gambar 2.

Rerata nilai kesukaan panelis terhadap warna kembang gula jelly mempunyai nilai terendah 2,63 didapatkan dari bahan pengenyal tepung agar-agar $4 \% \mathrm{~b} / \mathrm{b}$ dan $8 \% \mathrm{~b} / \mathrm{b}$, sedangkan nilai tertinggi 3,67 didapatkan dari bahan pengenyal tepung karaginan $6 \% \mathrm{~b} / \mathrm{b}$, hal ini dikarenakan kembang gula jelly yang mempergunakan bahan pengenyal tepung karaginan mempunyai warna yang lebih jernih dibandingkan dengan 


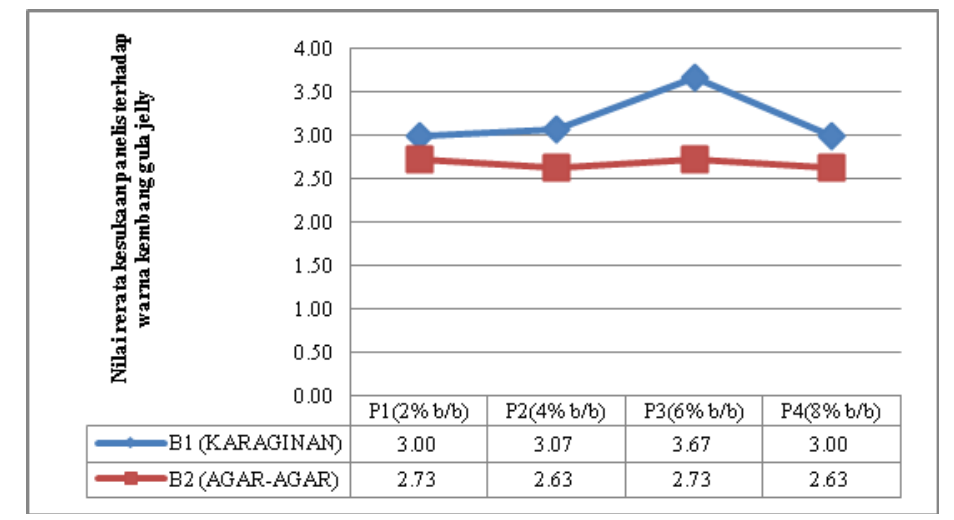

Gambar 2. Rerata kesukaan panelis terhadap warna kembang gula jelly

kembang gula jelly yang menunjukkan kualitas yang semakin mempergunakan bahan pengenyal baik, kembang gula jelly berbahan tepung agar-agar.

Hasil analisis Uji Friedman menunjukkan bahwa pembuatan kembang gula jelly dengan dua jenis bahan pengenyal (tepung karaginan dan tepung agar-agar) serta dengan empat variasi persentase $(2 \% \mathrm{~b} / \mathrm{b}, 4 \%$ b/b, 6\% b/b dan $8 \%$ b/b) memberikan pengaruh nyata terhadap rerata kesukaan warna kembang gula jelly. Kombinasi perlakuan terbaik tingkat kesukaan warna diperoleh dari kembang gula jelly berbahan pengenyal karaginan dengan persentase $6 \% \mathrm{~b} / \mathrm{b}$.

Warna merupakan hasil pengamatan dengan penglihatan yang dapat membedakan antara satu warna dengan warna lainnya, cerah, buram, bening, dan sebagainya. Salah satu sifat kembang gula adalah memiliki warna jernih, semakin jernih suatu produk kembang gula jelly maka akan pengenyal karaginan dengan persentase $6 \% \mathrm{~b} / \mathrm{b}$ lebih disukai panelis karena memiliki tingkat kejernihan yang paling baik.

Aroma

Aroma merupakan indikator yang penting dalam industri pangan karena dengan cepat dapat memberikan hasil penilaian diterima atau tidaknya produk tersebut. Aroma (“odour") meliputi berbagai sifat seperti harum, amis, apek, busuk, dan sebagainya.

Aroma atau bau sendiri sukar untuk diukur sehingga biasanya menimbulkan pendapat yang berlainan dalam menilai kualitas aromanya (Kartika 1988). Perbedaan pendapat disebabkan tiap orang memiliki perbedaan penciuman meskipun mereka dapat membedakan aroma namun setiap orang mempunyai kesukaan yang berlainan. 
Hasil uji organoleptik menunjukkan bahwa rerata ranking kesukaan panelis terhadap aroma kembang gula jelly berkisar antara 2,53 - 3,83. Semakin tinggi rerata ranking kesukaan panelis, maka tingkat kesukaan panelis terhadap aroma dengan bertambahnya prosentase bahan pengenyal yang digunakan.

Hasil analisis Uji Friedman menunjukkan bahwa pembuatan kembang gula jelly dengan dua jenis bahan pengenyal (tepung karaginan dan tepung agar-agar) serta dengan

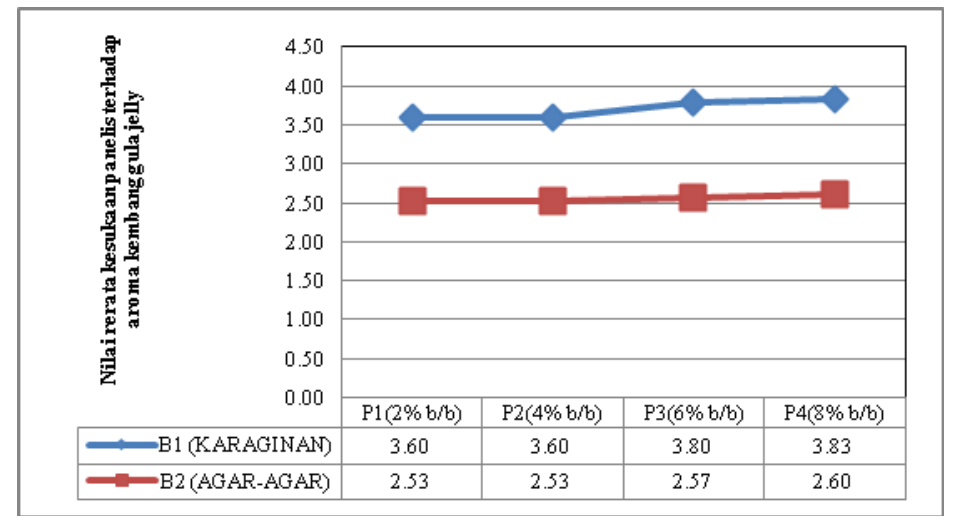

Gambar 3. Rerata kesukaan panelis terhadap aroma kembang gula jelly

kembang gula jelly semakin besar. Rerata ranking tingkat kesukaan panelis terhadap aroma kembang gula jelly ditunjukkan pada Gambar 3.

Rerata nilai kesukaan panelis terhadap aroma kembang gula jelly mempunyai nilai terendah 2,53 didapatkan dari bahan pengenyal tepung agar-agar $2 \% \mathrm{~b} / \mathrm{b}$ dan $4 \% \mathrm{~b} / \mathrm{b}$, sedangkan nilai tertinggi 3,83 didapatkan dari bahan pengenyal tepung karaginan $8 \% \mathrm{~b} / \mathrm{b}$, hal ini dikarenakan kembang gula jelly dengan bahan pengental tepung karaginan mempunyai aroma yang lebih harum dari pada tepung agar-agar dan tingkat keharumannya bertambah seiring empat variasi persentase $(2 \% \mathrm{~b} / \mathrm{b}, 4 \%$ b/b, $6 \%$ b/b dan $8 \%$ b/b) memberikan pengaruh nyata terhadap rerata kesukaan aroma kembang gula jelly. Kombinasi perlakuan terbaik tingkat kesukaan aroma diperoleh dari kembang gula jelly berbahan pengenyal karaginan dengan persentase $8 \%$ b/b. Hal ini disebabkan karena aroma tepung karaginan lebih harum dibandingkan dengan aroma tepung agar-agar sehingga mempengeruhi kembang gula jelly yang dihasilkan. Semakin besar persentase penambahan tepung karaginan aroma yang dihasilkan semakin harum dan disukai. 


\section{Tekstur}

Tekstur merupakan sensasi tekanan yang dapat diamati dengan melihat dan dirasakan pada waktu digigit, dikunyah, ditelan ataupun perabaan dengan jari (Kartika, 1988). Tekstur secara langsung dapat dilihat kenampakannya (dari luar) oleh konsumen sehingga berpengaruh terhadap penilaian diterima atau tidaknya produk tersebut. Tekstur
Rerata nilai kesukaan panelis terhadap tekstur kembang gula jelly mempunyai nilai terendah 2,13 didapatkan dari bahan pengenyal tepung agar-agar $2 \% \mathrm{~b} / \mathrm{b}$, sedangkan nilai tertinggi 4,13 didapatkan dari bahan pengenyal tepung karaginan $6 \%$ $\mathrm{b} / \mathrm{b}$.

Hasil analisis Uji Friedman menunjukkan bahwa pembuatan kembang gula jelly dengan dua jenis

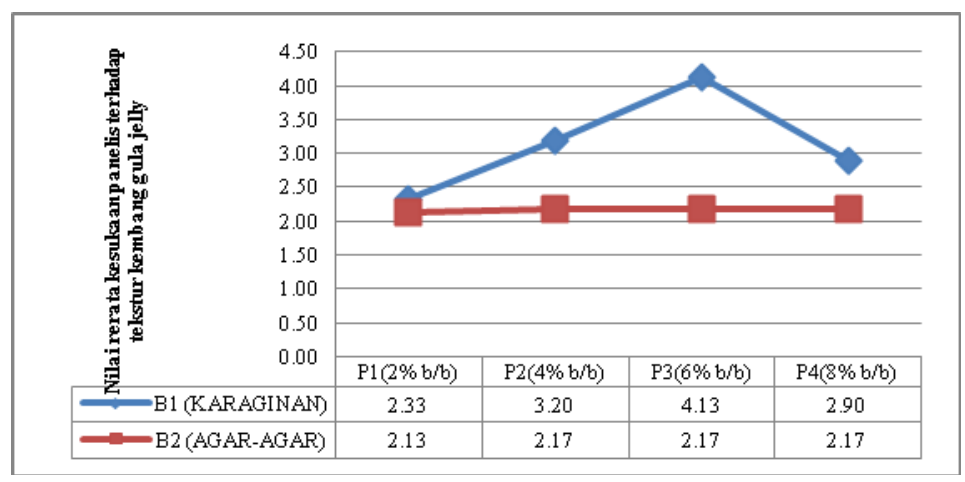

Gambar 4. Rerata kesukaan panelis terhadap tekstur kembang gula jelly

(konsistensi) adalah hasil pengamatan yang berupa sifat lunak, liat, keras, halus, kasar, dan sebagainya.

Hasil uji organoleptik menunjukkan bahwa rerata ranking kesukaan panelis terhadap tekstur kembang gula jelly berkisar antara 2,13 - 4,13. Semakin tinggi rerata ranking kesukaan panelis, maka tingkat kesukaan panelis terhadap tekstur kembang gula jelly semakin besar. Rerata ranking tingkat kesukaan panelis terhadap tekstur kembang gula jelly ditunjukkan pada Gambar 4. bahan pengenyal (tepung karaginan dan tepung agar-agar) serta dengan empat variasi persentase $(2 \% \mathrm{~b} / \mathrm{b}, 4 \%$ b/b, 6\% b/b dan 8\% b/b) memberikan pengaruh nyata terhadap rerata kesukaan tekstur kembang gula jelly. Kombinasi perlakuan terbaik tingkat kesukaan tekstur diperoleh dari kembang gula jelly berbahan pengenyal karaginan dengan persentase $6 \%$ b/b. Hal ini disebabkan karena bahan pengenyal tepung karaginan menghasilkan tekstur kembang gula jelly yang lunak 
dan bersifat seperti karet sedangkan tepung agar-agar menghasilkan tekstur kembang gula jelly yang lunak tetapi rapuh sehingga kurang disukai.

Persentase karaginan $6 \%$ b/b dinilai pas oleh sebagian besar panelis karena apabila persentase ditambah menjadi $8 \% \mathrm{~b} / \mathrm{b}$ menghasilkan kembang gula jelly yang keras dan terlalu liat, apabila dikurangi akan menghasilkan kembang gula jelly yang terlalu lembek dan berair.

\section{Pemilihan alternatif terbaik penelitian tahap I}

Penentuan perlakuan terbaik kembang gula jelly pada penelitian tahap I dilakukan dengan menggunakan metode indeks efektivitas (De Garmo, Sullivan dan Canada, 1984). Metode ini dilakukan pada parameter organoleptik meliputi, rasa, warna, aroma dan tekstur. Bobot parameter tertinggi adalah rasa dengan bobot 0,475 diikuti masing-masing tekstur 0,357 warna
0,244 serta aroma 0,181. Penilaian perlakuan terbaik disajikan pada Tabel 1.

Hasil perhitungan (Lampiran 8) menunjukkan kombinasi perlakuan terbaik pada tahap penelitian I pembuatan kembang gula jelly diperoleh dari kembang gula jelly berbahan pengenyal tepung karaginan dengan persentase $6 \% \mathrm{~b} / \mathrm{b}$ dengan karakteristik sebagai berikut: rerata tingkat kesukaan panelis terhadap rasa 3,73 ; warna 3,67 ; aroma 3,80 dan tekstur 4,13.

\section{Penelitian tahap II}

Penelitian tahap II bertujuan untuk menentukan persentase penambahan kulit buah naga super merah (Hylocereus costaricensis) yang optimal dalam pembuatan kembang gula jelly kulit buah naga super merah. Penelitian ini menggunakan enam variasi persentase kulit buah naga super merah yaitu $0 \%$; $20 \%$; $40 \%$; $60 \%$; $80 \%$ dan $100 \%$. Pengamatan pada

Tabel 1. Penilaian perlakuan terbaik terhadap parameter organoleptik pada kembang gula jelly perlakuan jenis dan persentase bahan pengenyal.

\begin{tabular}{|l|c|}
\hline \multicolumn{1}{|c|}{ Kembang gula jelly } & Nilai Produk \\
\hline Tepung Karaginan 2\% b/b (B1P1) & 0,478 \\
\hline Tepung Karaginan 4\% b/b (B1P2) & 0,735 \\
\hline Tepung Karaginan 6\% b/b (B1P3) & $1,354 *$ \\
\hline Tepung Karaginan 8\% b/b (B1P4) & 0,635 \\
\hline Tepung Agar-agar 2\% b/b (B2P1) & 0,048 \\
\hline Tepung Agar-agar 4\% b/b (B2P2) & 0,009 \\
\hline Tepung Agar-agar 6\% b/b (B2P3) & 0,047 \\
\hline Tepung Agar-agar 8\% b/b (B2P4) & 0,030 \\
\hline$*=$ perlakuan terbaik & \\
\hline
\end{tabular}


penelitian tahap II meliputi uji kimiawi kadar air, kadar abu, gula reduksi, kadar serat kasar serta antioksidan (DPPH) serta uji organoleptik, rasa, warna, aroma dan tekstur.

\section{Kadar air}

Kadar air merupakan syarat mutu kembang gula jelly yang tercantum di dalam SNI kembang gula No. 3547.22008 bahwa kembang gula harus memiliki kadar air maksimal $20 \% \mathrm{~b} / \mathrm{b}$. Rerata kadar air kembang gula jelly kulit buah naga super merah pada berbagai kombinasi perlakuan persentase kulit buah naga super merah yang dihasilkan berkisar antara 20,60 20,94\%.

Hasil analisis sidik ragam
Tabel 2 menunjukkan uji BNT 5\% kombinasi perlakuan terbaik kadar air diperoleh dari bahan pengenyal karaginan $6 \% \mathrm{~b} / \mathrm{b}$ dengan penambahan kulit buah naga sebesar 100\% (100\% kulit tanpa penambahan daging buah naga super merah) yaitu 20,60\% dengan hasil yang tidak berbeda nyata dengan perlakuan penggunaan bahan pengenyal karaginan $6 \% \mathrm{~b} / \mathrm{b}$ dengan penambahan kulit buah naga super merah $80 \%$ dan sangat berbeda nyata dengan yang lain.

Menurut Winarno (1992) dalam bahan makanan, air merupakan komponen yang penting, karena air dapat mempengaruhi penampakan, tekstur, serta cita rasa makanan. Disamping itu kandungan air didalam

\section{Tabel 2. Rerata Kadar Air (\%) pada Berbagai Kombinasi Perlakuan}

\begin{tabular}{|c|c|c|}
\hline Kombinasi Perlakuan & $\begin{array}{c}\text { Rerata } \\
\text { Kadar Air (\%) } \\
\end{array}$ & BNT 5\% \\
\hline Karaginan $6 \%$ b/b g dengan kulit buah naga $0 \%$ & $20.94 \quad$ c & \multirow{6}{*}{0.0712} \\
\hline Karaginan 6\% b/b g dengan kulit buah naga $20 \%$ & 20.84 & \\
\hline Karaginan 6\% b/b g dengan kulit buah naga $40 \%$ & 20.81 & \\
\hline Karaginan 6\% b/b g dengan kulit buah naga $60 \%$ & 20.77 & \\
\hline Karaginan 6\% b/b g dengan kulit buah naga $80 \%$ & 20.66 & \\
\hline Karaginan $6 \%$ b/b g dengan kulit buah naga $100 \%$ & 20.60 & \\
\hline
\end{tabular}

menunjukkan bahwa adanya pengaruh yang sangat nyata antara persentase bahan pengenyal $6 \% \mathrm{~b} / \mathrm{b}$ dengan persentase kulit buah naga super merah (BNT 5\%) terhadap kadar air. Rerata nilai kadar air pada berbagai kombinasi perlakuan ditunjukkan pada Tabel 2. bahan makanan ikut menentukan daya tahan bahan tersebut.

Dari hasil pengujian kadar air pada keenam sampel belum memenuhi syarat mutu kembang gula jelly yang tercantum dalam SNI 3547.2-2008 yaitu maksimal 20\%, hal ini disebabkan karena proses pengeringan 
yang dilakukan kurang maksimal karena mempergunakan pengeringan dengan sinar matahari. Jika ingin mendapatkan hasil kadar air yang optimal maka sebaiknya digunakan pengering mekanis.

\section{Kadar abu}

Abu merupakan zat organik sisa hasil pembakaran suatu bahan organik. Kadar abu ada hubungannya dengan mineral suatu bahan. Mineral suatu bahan merupakan garam organik (garam-garam malat, oksalat, asetat, pektat) dan garam anorganik (garam fosfat, karbonat, klorida, sulfat dan nitrat) (Fennema, 1996). kombinasi perlakuan ditunjukkan pada Tabel 3.

Tabel 3 menunjukkan uji BNT 5\% kombinasi perlakuan terbaik kadar abu diperoleh dari bahan pengenyal karaginan $6 \% \mathrm{~b} / \mathrm{b}$ dengan penambahan kulit buah naga sebesar 0\% (tanpa penambahan kulit buah naga super merah) yaitu $1,11 \%$ dengan hasil yang tidak berbeda nyata dengan perlakuan penggunaan bahan pengenyal karaginan $6 \% \mathrm{~b} / \mathrm{b}$ dengan penambahan kulit buah naga super merah $20 \% ; 40 \%$; 60\% dan sangat berbeda nyata dengan persentase penambahan kulit $80 \%$ dan $100 \%$.

Abu sendiri adalah hasil reaksi

Tabel 3. Rerata Kadar Abu (\%) pada Berbagai Kombinasi Perlakuan

\begin{tabular}{|c|c|c|}
\hline Kombinasi Perlakuan & $\begin{array}{c}\text { Rerata } \\
\text { Kadar Abu (\%) } \\
\end{array}$ & BNT 5\% \\
\hline Karaginan 6\% b/b g dengan kulit buah naga 0\% & 1.11 & \multirow{6}{*}{0.0704} \\
\hline Karaginan 6\% b/b g dengan kulit buah naga 20\% & 1.12 & \\
\hline Karaginan 6\% b/b g dengan kulit buah naga $40 \%$ & 1.15 & \\
\hline Karaginan $6 \%$ b/b g dengan kulit buah naga $60 \%$ & 1.15 & \\
\hline Karaginan 6\% b/b g dengan kulit buah naga 80\% & 1.22 & \\
\hline Karaginan 6\% b/b g dengan kulit buah naga $100 \%$ & 1.27 & \\
\hline
\end{tabular}

Keterangan: Angka rerata yang diikuti dengan huruf yang sama pada kolom yang sama tidak berbeda nyata pada uji BNT 5\%

Rerata kadar abu pada berbagai kombinasi perlakuan persentase penambahan kulit buah naga super merah berkisar antara $1,11-1,27 \%$.

Hasil analisis sidik ragam menunjukkan bahwa adanya pengaruh yang sangat nyata antara persentase bahan pengenyal $6 \% \mathrm{~b} / \mathrm{b}$ dengan persentasse kulit buah naga super merah (BNT 5\%) terhadap kadar abu. Rerata nilai kadar abu pada berbagai unsur logam dengan oksigen, karena logam masa jenis lebih besar maka oksidanya tertinggal sebagai abu, sementara oksida non logam misal CO2 karena ringan maka terbang sebagai asap.

Dari hasil pengujian kadar abu pada keenam sampel sudah memenuhi syarat mutu kembang gula jelly yang tercantum dalam SNI3547.2-2008 yaitu maksimal 3\%. 


\section{Gula reduksi}

Perbedaan kandungan gula reduksi dalam variasi perlakuan penelitian ini disebabkan oleh perbedaan kadar gula pada daging dan kulit buah naga super merah. Dalam daging buah naga super merah mengandung kadar gula yang cukup tinggi yaitu mencapai 13-18 briks (Anonymous.2008h).

Rerata kandungan gula reduksi pada berbagai kombinasi perlakuan persentase penambahan kulit buah naga super merah berkisar antara 20,70\% $20,72 \%$. kulit buah naga sebesar 100\% yaitu 20,70\% dengan hasil yang tidak berbeda nyata dengan perlakuan penggunaan bahan pengenyal karaginan $6 \% \mathrm{~b} / \mathrm{b}$ dengan penambahan kulit buah naga super merah $80 \%$ dan $60 \%$ dan sangat berbeda nyata dengan persentase penambahan kulit lainnya.

Pada dasarnya reaksi inversi sukrosa menjadi gula reduksi adalah reaksi hidrolisis. Menurut Risvan Kuswurj (2009) dalam Sugar Technology and Research, kerugian dari gula invert antara lain, mudah menyebabkan produk menjadi basah,

Tabel 4. Rerata Gula reduksi (\%) pada Berbagai Kombinasi Perlakuan

\begin{tabular}{|c|c|c|}
\hline Kombinasi Perlakuan & $\begin{array}{c}\text { Rerata } \\
\text { Gula reduksi (\%) } \\
\end{array}$ & BNT 5\% \\
\hline Karaginan $6 \%$ b/b g dengan kulit buah naga $0 \%$ & 20.72 & \multirow{6}{*}{0.00499} \\
\hline Karaginan 6\% b/b g dengan kulit buah naga 20\% & 20.72 & \\
\hline Karaginan 6\% b/b g dengan kulit buah naga 40\% & 20.71 & \\
\hline Karaginan 6\% b/b g dengan kulit buah naga 60\% & 20.71 & \\
\hline Karaginan 6\% b/b g dengan kulit buah naga $80 \%$ & 20.70 & \\
\hline Karaginan 6\% b/b g dengan kulit buah naga $100 \%$ & 20.70 & \\
\hline
\end{tabular}

Hasil analisis sidik ragam menunjukkan bahwa adanya pengaruh yang sangat nyata antara persentase bahan pengenyal $6 \% \mathrm{~b} / \mathrm{b}$ dengan persentase kulit buah naga super merah (BNT 5\%) terhadap kandungan gula reduksi. Rerata nilai gula reduksi pada berbagai kombinasi perlakuan ditunjukkan pada Tabel 4.

Tabel 4 menunjukkan uji BNT 5\% kombinasi perlakuan terbaik gula reduksi diperoleh dari bahan pengenyal karaginan $6 \% \mathrm{~b} / \mathrm{b}$ dengan penambahan afinitas dalam air tinggi, memberikan efek karamelisasi, menyebabkan warna menjadi kecoklatan.

Dari hasil pengujian kadar gula reduksi pada keenam sampel sudah memenuhi standar mutu kembang gula jelly yang tercantum dalam SNI 3547.2-2008 yaitu maksimal 25\%.

\section{Kadar serat kasar}

Kandungan serat buah naga mencapai 0,7-0,9 gram per 100 gram daging buah dan sangat baik untuk 
menurunkan kadar kolesterol. Di dalam saluran pencernaan, serat akan mengikat asam empedu (produk akhir kolesterol) yang kemudian dikeluarkan bersama tinja. Dengan demikian, semakin tinggi konsumsi serat, semakin banyak asam empedu dan lemak yang dikeluarkan oleh tubuh.

Rerata kadar serat kasar pada berbagai kombinasi perlakuan persentase penambahan kulit buah naga super merah berkisar antara 1,06\% $1,43 \%$. tidak berbeda nyata dengan perlakuan penggunaan bahan pengenyal karaginan $6 \% \mathrm{~b} / \mathrm{b}$ dengan penambahan kulit buah naga super merah $80 \%$ dan $60 \%$ dan sangat berbeda nyata dengan persentase penambahan kulit 20\% dan 0\%.

Dari hasil pengujian kadar serat kasar pada keenam sampel diketahui bahwa kadar serat kasarnya lebih tinggi dari pada serat yang terkandung dalam daging buah naga super merah segar yaitu $0,7-0,9$ gram per 100 gram daging buah naga super merah, hal ini

Tabel 5. Rerata Kadar Serat Kasar (\%) pada Berbagai Kombinasi Perlakuan

\begin{tabular}{|c|c|c|}
\hline Kombinasi Perlakuan & $\begin{array}{c}\text { Rerata } \\
\text { Kadar Serat Kasar } \\
(\%)\end{array}$ & BNT 5\% \\
\hline Karaginan 6\% b/b g dengan kulit buah naga $0 \%$ & 1.06 & \multirow{6}{*}{0.05783} \\
\hline Karaginan 6\% b/b g dengan kulit buah naga $20 \%$ & 1.24 & \\
\hline Karaginan 6\% b/b g dengan kulit buah naga $40 \%$ & 1.40 & \\
\hline Karaginan 6\% b/b g dengan kulit buah naga $60 \%$ & 1.41 & \\
\hline Karaginan 6\% b/b g dengan kulit buah naga 80\% & 1.42 & \\
\hline Karaginan 6\% b/b g dengan kulit buah naga 100\% & 1.43 & \\
\hline
\end{tabular}

Hasil analisis sidik ragam disebabkan adanya penambahan serat menunjukkan bahwa adanya pengaruh kasar dari bahan tambahan lainnya yang sangat nyata antara persentase yaitu tepung karaginan yang bahan pengenyal $6 \% \mathrm{~b} / \mathrm{b}$ dengan merupakan sumber serat yang tinggi. persentase kulit buah naga super merah Kadar air bahan juga berpengaruh (BNT 5\%) terhadap kadar serat kasar. terhadap tingginya serat kasar yang Rerata nilai kadar serat kasar pada diuji dimana kadar air daging buah berbagai kombinasi perlakuan naga super merah segar adalah 82,5 ditunjukkan pada Tabel 5.

Tabel 5 menunjukkan uji BNT 5\% kombinasi perlakuan terbaik kadar serat kasar diperoleh dari bahan pengenyal karaginan $6 \% \mathrm{~b} / \mathrm{b}$ dengan penambahan kulit buah naga sebesar $100 \%$ sebesar 1,43\% dengan hasil yang 
Menurut Goldberg

kandungan serat pada buah naga juga sangat berguna dalam sistem pencernaan. Serat pangan (dietary fiber) mampu memperpendek transit time, yaitu waktu yang dibutuhkan makanan sejak dari rongga mulut hingga sisa makanan dikeluarkan dalam bentuk feses. Di dalam saluran pencernaan serat akan mengikat asam empedu (produk akhir kolesterol) dan kemudian dikeluarkan bersama fases. Dengan demikian, semakin tinggi konsumsi serat, semakin banyak asam empedu dan lemak yang dikeluarkan oleh tubuh. Disebutkan pula bahwa serat pangan sangat baik untuk mencegah penyakit diabetes melitus, jantung, stroke, kanker, dan penyakit kardiovaskular lainnya. Sayangnya, konsumsi serat di Indonesia saat ini masih sangat rendah, yaitu sekitar 10 gram per orang per hari. Padahal, konsumsi serat pangan yang dianjurkan adalah 20-30 gram per orang per hari.

\section{Antioksidan}

Antioksidan merupakan senyawa yang akan menghambat atau menunda proses oksidasi substrat pada konsentrasi yang rendah (Vaya dan Aviram, 2001). Secara umum, antioksidan mengurangi kecepatan reaksi inisiasi pada reaksi berantai pembentukan radikal bebas dalam konsentrasi yang sangat kecil, yaitu 0,01\% atau bahkan kurang (Madhavi et al., 1995). Karakter utama senyawa antioksidan adalah kemampuannya untuk menangkap radikal bebas (Prakash et al., 2001).
Pengujian aktivitas antioksidan dalam penelitian ini menggunakan metoda efek penangkapan radikal bebas DPPH (Diphenyl Picryl Hydrazil) yang prinsipnya adalah penangkapan hidrogen dari antioksidan oleh radikal bebas. Dalam hal ini DPPH menjadi sumber radikal bebas, untuk dipertemukan dengan ekstrak kembang gula jelly kulit buah naga super merah yang menjadi antioksidan.

Rerata kadar antioksidan (DPPH) pada berbagai kombinasi perlakuan persentase penambahan kulit buah naga super merah berkisar antara $6,49 \%-6,91 \%$.

Hasil analisis sidik ragam menunjukkan bahwa adanya pengaruh yang sangat nyata antara persentase bahan pengenyal $6 \% \mathrm{~b} / \mathrm{b}$ dengan persentase kulit buah naga super merah (BNT 5\%) terhadap kadar antioksidan. Rerata nilai kadar antioksidan pada berbagai kombinasi perlakuan ditunjukkan pada Tabel 6.

Tabel 6 menunjukkan uji BNT 5\% kombinasi perlakuan terbaik kadar antioksidan diperoleh dari bahan pengenyal karaginan $6 \% \mathrm{~b} / \mathrm{b}$ dengan penambahan kulit buah naga sebesar 0\% (tanpa penambahan kulit buah naga super merah) sebesar 6,91\% dengan hasil yang sangat berbeda nyata dengan perlakuan lainnya 
Tabel 6. Rerata Kadar Antioksidan (\%) pada Berbagai Kombinasi Perlakuan

\begin{tabular}{|c|c|c|}
\hline Kombinasi Perlakuan & $\begin{array}{c}\text { Rerata Kadar } \\
\text { Antioksidan (\%) }\end{array}$ & BNT 5\% \\
\hline Karaginan 6\% b/b g dengan kulit buah naga $0 \%$ & 6.91 & \multirow{6}{*}{0.0679} \\
\hline Karaginan $6 \%$ b/b g dengan kulit buah naga $20 \%$ & 6.85 & \\
\hline Karaginan $6 \%$ b/b g dengan kulit buah naga $40 \%$ & 6.79 & \\
\hline Karaginan 6\% b/b g dengan kulit buah naga $60 \%$ & 6.68 & \\
\hline Karaginan 6\% b/b g dengan kulit buah naga $80 \%$ & 6.56 & \\
\hline Karaginan $6 \%$ b/b g dengan kulit buah naga $100 \%$ & 6.49 & \\
\hline
\end{tabular}

Keterangan: Angka rerata yang diikuti dengan huruf yang sama pada kolom yang sama tidak berbeda nyata pada uji BNT 5\%

\begin{tabular}{|c|c|}
\hline $\begin{array}{l}\text { Dari hasil penelitian didapatkan } \\
\text { bahwa semakin besar persentase } \\
\text { penambahan kulit buah naga super } \\
\text { merah maka aktivitas antioksidannya } \\
\text { semakin menurun, dimana DPPH } \\
\text { tertinggi pada perlakuan tanpa }\end{array}$ & $\begin{array}{l}\text { daging buah. Hal ini membuktikan } \\
\text { bahwa kandungan antioksidan pada } \\
\text { kulit lebih rendah daripada daging } \\
\text { buahnya meskipun perbedaanya sangat } \\
\text { kecil. }\end{array}$ \\
\hline $\begin{array}{l}\text { enambahan kulit dan nila } \\
\text { ada perlakuan tanpa }\end{array}$ & $\begin{array}{l}\text { Service (ARS), United States } \\
\text { Department of }\end{array}$ \\
\hline
\end{tabular}

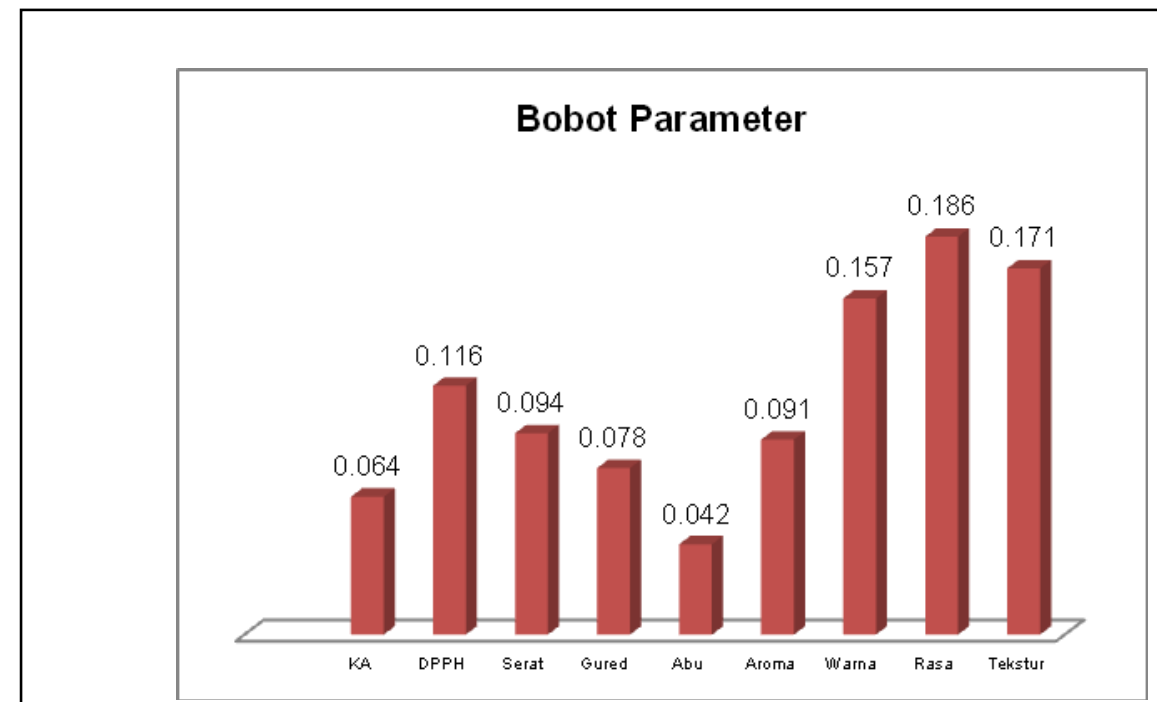

Gambar 6. Bobot Parameter Penelitian Tahap II Kembang Gula Jelly Kulit Buah Naga Super Merah 
dalam Pratomo (2007), buah naga berdaging merah mengandung total fenolat $1.076 / \mathrm{mol}$ gallic acid equivalents (GAE)/g puree. Aktivitas antioksidan mencapai 7,59/mol trolox equivalents (TE)/g puree. Sedangkan yang berdaging putih Hylocereus undatus mengandung total fenolat 523 /mol GAE/g dan aktivitas antioksidan 2,96 /mol TE/g.

\section{Pemilihan alternatif terbaik penelitian tahap II}

Penentuan perlakuan terbaik kembang gula jelly kulit buah naga super merah pada penelitian tahap II dilakukan dengan menggunakan metode indeks efektivitas (De Garmo, Sullivan dan Canada, 1984). Metode ini dilakukan pada parameter kimiawi meliputi uji kadar air, kadar abu, gula reduksi, kadar serat kasar serta antioksidan (DPPH) serta uji
0.157 ; antioksidan (DPPH) 0.116 ; serat kasar 0.094 ; aroma 0.091 ; gula reduksi 0.078 ; kadar air 0.064 dan kadar abu 0.042. Bobot parameter disajikan pada Gambar 6.

Sedangkan penilaian perlakuan terbaik kembang gula jelly kulit buah naga super merah disajikan pada Tabel 7 .

Hasil perhitungan menunjukkan kombinasi perlakuan terbaik pada penelitian tahap II pembuatan kembang gula jelly kulit buah naga super merah diperoleh dari kembang gula jelly kulit buah naga super merah dengan persentase penambahan kulit sebesar $100 \%$ dengan karakteristik sebagai berikut: rerata kadar air 20.602\% ; kadar abu $1.267 \%$; gula reduksi $20.700 \%$; serat kasar $1.428 \%$; antioksidan (DPPH) $6.493 \%$ serta rerata tingkat kesukaan panelis terhadap rasa 3.900 ; warna 4.667 ; aroma 3.533 dan tekstur 4.100 .

Tabel 7. Penilaian perlakuan terbaik terhadap parameter kimiawi dan organoleptik pada kembang gula jelly kulit buah naga super merah perlakuan persentase penambahan kulit buah naga super merah.

\begin{tabular}{|l|c|}
\hline \multicolumn{1}{|c|}{ Kembang gula jelly kulit buah naga super merah } & Nilai Produk \\
\hline Persentase Kulit $0 \%$ & 0.458 \\
\hline Persentase Kulit $20 \%$ & 0.481 \\
\hline Persentase Kulit $40 \%$ & 0.472 \\
\hline Persentase Kulit $60 \%$ & 0.386 \\
\hline Persentase Kulit $80 \%$ & 0.462 \\
\hline Persentase Kulit $100 \%$ & $0.542 *$ \\
\hline
\end{tabular}

organoleptik, rasa, warna, aroma dan tekstur. Bobot parameter tertinggi adalah rasa dengan bobot 0.186 diikuti Analisis Finansial masing-masing tekstur 0.171 ; warna Analisis finansial dilakukan untuk mengetahui tingkat kelayakan 
unit pengolahan pembuatan produk kembang gula jelly kulit buah naga super merah. Analisis finansial meliputi analisis kebutuhan modal, biaya operasional, analisis Break Event Point (BEP), dan analisis kelayakan investasi yang meliputi perhitungan Payback Periode, Net Present Value, dan Profitability Index. Ringkasan hasil analisis finansial solusi optimal dapat dilihat pada Tabel 8.

\section{Biaya Produksi}

Total biaya produksi selama 1 tahun kembang gula jelly kulit buah naga super tenaga kerja dan biaya overhead pabrik (Husnan dan Sudarsono, 1994).

\section{Harga Pokok Produksi (HPP)}

Harga Pokok Produksi (HPP) sebesar Rp. 31,981,-/Kg. Harga jual yang dihitung di tingkat produsen ke pengecer sebesar Rp. 40,000,-/Kg dengan asumsi pengambilan mark up sebesar $53,90 \%$ dari setiap produk unit yang terjual. Menurut Fatchi (2004), besarnya mark up di tingkat produsen langsung ke konsumen sebesar 20\%, jika melalui agen sampai ke pengecer besarnya mark up 50\%, dan bila

Tabel 8. Ringkasan hasil analisis finansial kembang gula jelly kulit buah naga super merah dengan kapasitas $10 \mathrm{Kg} / \mathrm{hari}$.

\begin{tabular}{|c|l|r|}
\hline No. & \multicolumn{1}{|c|}{ Komponen } & \multicolumn{1}{c|}{ Jumlah (Rp) } \\
\hline 1 & Biaya Tetap selama 1 tahun (FC) & $60,615,120$ \\
\hline 2 & Biaya Tidak Tetap selama 1 tahun (VC) & $31,490,537$ \\
\hline 3 & Total Biaya Produksi selama 1 tahun (TC) & $92,105,657$ \\
\hline 4 & Jumlah Produksi selama 1 tahun (kg) Q & 2,880 \\
\hline 5 & Biaya tidak tetap selama 1 tahun per kg (VC per kg) & 10,934 \\
\hline 5 & HPP (Rp)= TC/Q & 31,981 \\
\hline 6 & Mark Up (53,90\%) & 7,394 \\
\hline 7 & Harga Jual (Rp) (P) & 40,000 \\
\hline 8 & BEP (unit) & 2,131 \\
\hline 9 & BEP (Rp) & $83,918,794$ \\
\hline
\end{tabular}

merah adalah sebesar Rp. 92,105,657,dengan perincian biaya tetap (fixed cost) sebesar Rp. 60,615,120,- dan biaya tidak tetap (variable cost) sebesar Rp. 31,490,537,- . Perhitungan biaya produksi dilakukan dalam periode 1 tahun yang merupakan jumlah keseluruhan dari biaya tetap dan biaya tidak tetap dalam 1 tahun yang melibatkan biaya bahan baku, biaya

pengecer menjual produk ke konsumen akhir mark up yang ditentukan sebesar $70 \%$. Sehingga diperkirakan pengecer menjual produk ke konsumen akhir dengan mark up 70\%, maka diperkirakan harga produk sampai ke konsumen sebesar Rp 55,000,- /Kg. Harga jual di tingkat konsumen ini jika dibandingkan dengan produk sebanding yang ada di pasaran, maka harga 
produk kembang gula kulit buah naga super merah hasil penelitian relatif lebih murah dimana harga produk sejenis yang dijual curah di pasaran mempunyai harga Rp. 77,000,-/Kg.

\section{Break Event Point (BEP)}

Break Event Point (BEP) merupakan titik impas, dimana nilai penjualan atau pendapatan sama dengan total biaya. Analisis BEP tersebut merupakan cara untuk mengetahui volume penjualan minimal agar suatu usaha tidak mengalami kerugian tetapi juga belum memperoleh laba (laba sama atau dengan 0). BEP sangat sensitif terhadap perubahan fixed operating cost, variable operating cost per unit dan harga jual per unit hasil produksi perusahaan. Hasil perhitungan BEP menunjukkan bahwa titik balik pokok akan dicapai pada volume penjualan $2.131 \mathrm{Kg}$ atau senilai Rp. 83,918,794,-. Apabila perusahaan telah mencapai angka penjualan tersebut di atas, maka dapat diartikan bahwa perusahaan telah mencapai titik dimana perusahaan tidak mengalami kerugian maupun memperoleh keuntungan.

\section{Payback Period (PP)}

Payback Period merupakan metode yang digunakan untuk mengukur kecepatan pengembalian modal investasi yang dinyatakan dalam tahun. Hasil perhitungan pada menunjukkan bahwa nilai payback period dicapai pada 1 tahun 3 bulan 21 hari. Hal ini menunjukkan bahwa dalam jangka waktu tersebut nilai investasi usaha sebesar Rp. 91,873,996,- telah kembali. Lama payback period lebih pendek daripada umur proyek yang direncanakan yaitu selama 5 tahun, sehingga dapat dikatakan proyek ini layak untuk dilaksanakan.

\section{Net Present Value (NPV)}

Nilai Net Present Value (NPV) bernilai positif atau lebih besar dari nol, yaitu sebesar Rp. 52.868.819,-, dengan demikian unit usaha industri kembang gula kulit buah naga super merah layak dilaksanakan.

\section{Profitability Index (PI)}

Nilai Profitability Index (PI) bernilai positif atau lebih besar dari nol, yaitu sebesar 1.575, dengan demikian unit usaha industri kembang gula kulit buah naga super merah layak dilaksanakan.

\section{KESIMPULAN DAN SARAN \\ Kesimpulan}

Kombinasi perlakuan terbaik berdasarkan indeks efektifitas pada penelitian tahap I diperoleh dari kombinasi perlakuan B1P3 yaitu kembang gula jelly dengan bahan pengenyal tepung karaginan dengan persentase $6 \% \mathrm{~b} / \mathrm{b}$ dengan nilai produk 1,354 yang memiliki karakteristik sebagai berikut: rerata tingkat kesukaan panelis terhadap rasa 3,73 ; warna 3,67 ; aroma 3,80 dan tekstur 4,13.

Pada tahap II, berdasarkan indeks efektifitas kombinasi perlakuan bahan pengenyal tepung karaginan $6 \% \mathrm{~b} / \mathrm{b}$ dengan campuran kulit buah naga super merah tanpa tambahan daging buahnya (kulit 100\%) merupakan perlakuan terbaik dengan nilai produk 0.542 yang 
memiliki karakteristik sebagai berikut: rerata kadar air 20.602\% ; kadar abu $1.267 \%$; gula reduksi $20.700 \%$; serat kasar 1.428\% ; antioksidan (DPPH) 6.493\% serta rerata tingkat kesukaan panelis terhadap rasa 3.900 ; warna 4.667 ; aroma 3.533 dan tekstur 4.100.

Perhitungan BEP dicapai pada volume penjualan $2.131 \mathrm{Kg}$ atau senilai Rp. 83,918,794,-. Nilai payback period dicapai pada 1 tahun 3 bulan 21 hari. Nilai Net Present Value (NPV) sebesar Rp. 52.868.819,-. Nilai Profitability Index (PI) sebesar 1.575 dengan demikian unit usaha industri kembang gula jelly kulit buah naga super merah layak dilaksanakan.

\section{Saran}

Perlu dikaji penelitian lebih lanjut tentang pembuatan sirup kulit buah naga super merah (Hylocereus costaricensis) sehingga kontinuitas bahan baku dapat terjaga dan kapasitas produksi dapat ditingkatkan sepanjang tahun mengingat buah naga super merah termasuk dalam buah musiman.

\section{DAFTAR RUJUKAN}

Anonymous. 2002. Genetic resource and conservation. DurioA.Bibiographic Review. http:// www.ipgri.cgiar.org.region/expo /publication/durio.htm. Agustus, 2009. 2004. Manfaat Rumput Laut dan Algae. Artikel Seaweed.

http://rumputlaut.org/datalama/ar tikel/Manfaat\%20Rumput\%20La
ut\%20dan\%20Algae.pdf. Akses 12 Desember 2009.

Teknologi Pangan dan Agroindustri. Vol. 1. Nomor 10. Jurusan Teknologi Pangan dan Gizi IPB. Bogor.

2007b. Hylocereus polyrhizus Buah Naga. Jabatan Pertanian Sabah. Unit Perkhidmatan Pengembangan Pertanian .Pejabat Pertanian Tawau.

Afrianto, E dan E, Liviawati, 1989. Budidaya Rumput Laut dan Cara Pengolahannya. Bhatara. Jakarta.

Angkasa, Wisman Indra, Heri Purwoto, Jana Anggadiredja. 2008. Teknik Budidaya Rumput Laut.

http://kenshuseidesu.tripod.com. Akses 10 Desember 2009.

AOAC, 1990. Association of Official Analytical Chemist Official Methods of Analysis food composition. $15^{\text {th }}$ edition. Vol II. Agricultural chemical; Contaminants; Drugs.

Apriadji, W.H. 2002a. Makanan juga bisa berfungsi sebagai obat. Sedap Sekejap Edisi 7/II: 72

Apriadji, W.H.2002b. Manfaat sehat food combining. Sedap Sekejap Edisi7/III:70 
A/S Kobenhvs Pektifabrik, 1978. Carrageenan. Lilleskensved. Denmark
Aslan, L.M 1991. Seri Budi Daya Rumput laut.
Kanisius.Yogyakarta

Aslan, L.M 1998. Seri Budi Daya Rumput

laut.

Kanisius.Yogyakarta

Astawan, Made. 2007a. Agar-agar Pencegah Hipertensi dan Diabetes.

http://askara09.wordpress.com.

Akses 14 Oktober 2009.

Djadmika, Eko. 1988. Pembuatan Minuman Berkarbon Sari Lidah Buaya (Aloe Vera). Institut Pertanian Bogor.

DKP. 2008. Dorong Rumput Laut Sebagai Sumber Pangan Dan Energi. Siaran Pers No. 66/PDSI/X/2008

http://www.dkp.go.id Akses 23 Juli 2009

Doty MS. 1985. Eucheuma alvarezii sp.nov

(Gigartinales, Rhodophyta) from Malaysia. Di dalam: Abbot IA, Norris JN (editors). Taxonomy of Economic Seaweeds. California Sea Grant College Program. p 37 - 45.

Escribano, J., Pedreño, M.A., GarciaCarmona, F. \& Muñoz, R. 1998. Characterization of the Antiradical Activity of Betalains from Beta Vulgaris
L. Roots. Phytochemical Analysis 9: 124-127.

Evy Syariefa. 2009. Merah super. Trubus Majalah Pertanian Indonesia : Gao-Xi, A. and Wan, R. 2004. Study in producing piytaya ice cream. China-Dairy industry 32 (10): 9-11.

Glicksman M. 1983.. Gum Technology in the Food Industry. New York: Academic Press. p 214- 224.

Goldberg, I. 1994. Functional Foods. Chapman \& Hall. London, Englan duiseley and Renn, 1977

Halimah Abdullah Sani, Asmazila .B, Muhammad Azam. A \& Isma Illyani. I. 2009. Keberkesanan Ekstrak Hylocereus polyrhizus Merendahkan Lipid Serum dan Aras MDA-TBAR Hati Tikus Teraruh Hiperkolesterolemia ( Effectiveness of Hylocereus polyrhizus Extract in Decreasing Serum Lipids and Liver MDA-TBAR Level in Hypercholesterolemic Rats). Sains Malaysiana 38(2)(2009): 271-279.

Hambali,Erliza 2004. Membuat Aneka Olahan Rumput Laut. Penebar

Swadaya . Jakarta.

Hellebust JA, Cragie JS. 1978. Handbook of Phycological Methods. London:Cambridge University Press. p 54-66. 
Hidayat Nur, Ken Ikaristiana, 2006.

Membuat Permen Jelly. Trubus Agrisarana. Surabaya.

Kumalaningsih, Sri, 2006, Antioksidan Alami Penangkal Radikal Bebas. Trubus Agrisarana. Surabaya.

Langseth, Lilian. 1995. Oxidant, Antioxidant, and Disease Prevention. International Life Science Institute press. Belgium.
Li Chen Wu, Hsiu-Wen Hsu, YunChen Chen, Chih-Chung Chiu, Yu-In Lin and Annie Ho . 2005.

Antioxidant And

Antiproliferative Activities Of Red Pitaya . Department of Applied Chemistry, National Chi-Nan University, Nomor 1 University Road, Puli, Nantou, 545 Taiwan 
